\title{
DATA PAPER
}

\section{GERMINATION CAPACITY OF 75 HERBACEOUS SPECIES OF THE PANNONIAN FLORA AND IMPLICATIONS FOR RESTORATION}

\author{
R. Kiss ${ }^{1}$, J. Sonkoly ${ }^{2}$, P. TöröK², B. Tóthmérész ${ }^{3}$, B. DeÁK ${ }^{1}$, K. Tóth ${ }^{3}$, K. LukÁcs ${ }^{1}$ \\ L. Godó ${ }^{1}$, A. Kelemen ${ }^{1,4}$, T. Miglécz ${ }^{1}$, Sz. Radócz ${ }^{1}$, E. Tóth ${ }^{2}$, N. Balogh ${ }^{1}$ and O. Valkó ${ }^{1}$ \\ ${ }^{1}$ Department of Ecology, University of Debrecen, H-4032 Debrecen, Egyetem tér 1, Hungary; \\ E-mails: kissreka801@gmail.com, debalazs@gmail.com,lukacskata93@gmail.com, \\ godolaura0306@gmail.com, tamas.miglecz@gmail.com, radoczszilvia88@gmail.com, \\ balogh.nora.4@gmail.com,valkoorsi@gmail.com \\ ${ }^{2}$ MTA-DE Lendület Functional and Restoration Ecology Research Group \\ H-4032 Debrecen, Egyetem tér 1, Hungary; \\ E-mails: judit.sonkoly@gmail.com, molinia@gmail.com, toth.edina033@gmail.com \\ ${ }^{3} M T A-D E$ Biodiversity and Ecosystem Services Research Group \\ H-4032 Debrecen, Egyetem tér 1, Hungary; E-mails: tothmerb@gmail.com, kissa0306@gmail.com \\ ${ }^{4} M T A$ 's Post-Doctoral Research Programme, MTA TKI \\ H-1051 Budapest, Nádor utca 7, Hungary; E-mail: kelemen.andras12@gmail.com
}

(Received 25 January, 2018; Accepted 12 February, 2018)

Seeds ensure the survival and dispersal of the majority of vascular plant species. Seeds require species-specific germination conditions and display very different germination capacities using different germination methods. Despite the importance of plant generative reproduction, little is known about the germination capacity of the seeds of the Pannonian flora, particularly under field conditions. Our aim was to reduce this knowledge gap by providing original data on the germination capacity of 75 herbaceous species. We reported the germination capacity of 8 species for the first time. We also highlighted the year-to-year differences in the germination capacity of 11 species which could be highly variable between years. The data regarding the germination capacity of target species, as well as weeds and invasive species, can be informative for nature conservation and restoration projects. Our findings support the composition of proper seed mixtures for ecological restoration and also highlight the importance of testing seed germination capacity before sowing.

Key words: database, germination potential, germination rate, grassland restoration, regional flora

\section{INTRODUCTION}

Seeds are crucial in the reproduction and dispersal of plant species, and are important components of community resilience. Viable seeds germinate immediately after seed maturation or enter to a dormant state, which can last from a few days to years, forming a transient or persistent seed bank (Baskin 
and Baskin 1998, Molnár V. et al. 2015). Dormancy of seeds represents a way of bridging unfavourable conditions, enabling seeds to germinate only when all environmental conditions seem suitable for seedling survival (Valkó et al. 2014). In this way species and communities can survive unexpected events and unfavourable environmental conditions, such as fire, flood events or drought (Akinola et al. 1998, Bossuyt and Honnay 2008, Kimura and Tsuyuzaki 2011).

At the end of the dormant state, active metabolism is resumed and the seed germinates (Kozlowski 2012). To achieve germination, sufficient moisture supply, suitable temperature and proper aeration of the soil are crucial (Kozlowski 2012), although some species may have specific requirements (Baskin and Baskin 1998). For example, hard-coated seeds often require scarification or stratification in order to break their dormancy (Endrédi 2012, Endrédi et al. 2012, Lovas-Kiss et al. 2015, Patanè and Gresta 2006, Valkó et al. 2018). In the case of plants used in agriculture the International Seed Testing Association (ISTA) provides information about species specific requirements (ISTA 2018). Baskin and Baskin (1998) collected data from germination studies and formulated suggestions for future experiments. They suggested using seeds shortly after harvesting, otherwise their germination capacity can change during storage, or they can enter dormancy. If possible, factors such as water permeability should be tested, to check whether seeds can take in water and whether they are able to germinate. Optimal storage conditions are crucial to preserve seeds (Budelsky and Galatowitsch 1999). Baskin and Baskin (1998) also provided information on inducing germination and increasing germination rates for some species, and highlighted that several factors, such as temperature, moisture or salinity have to be tested to identify the most appropriate conditions (Covell et al. 1986, Gulzar and Khan 2001, Huang et al. 2003, Roberts 1988). To maximise germination rates, the most suitable germination method has to be identified (Peti et al. 2017).

Given that germination conditions are very species-specific, and testing germination is labour-intensive, data on the germination capacity of species are scarce. Germination capacity has mostly been studied for agricultural crops, as well as garden and ornamental plants (ISTA). In spite of the increasing involvement of seed traits in ecological research (Hintze et al. 2013, Kelemen et al. 2015, 2016, Török et al. 2013, 2016), we only found two databases, which contained information about the seed germination capacity of the wild plant species of the Central European flora (SID - RBGK 2018, HUSEED ${ }^{\text {wild }}$ - Peti et al. 2017). The large international plant trait databases lack such information (LEDA - Kleyer et al. 2008, D D $^{3}$ Hintze et al. 2013). Although many restoration experiments were conducted with seed sowing in Hungary (Deák et al. 2011, Török et al. 2010, 2011, Valkó et al. 2016), local data on germination capacity were hardly available for the Pannonian flora until recent times. The first germination percentage data of 744 taxa collected in Hungary were pub- 
lished online in the HUSEED ${ }^{\text {wild }}$ database (Peti et al. 2017, hereafter HUSEED). This database contains information about the germination capacity of seeds of the Pannonian flora under laboratory conditions, using wetted filter-paper as a germination substrate. They aimed at maximizing germination success so they tested multiple germination methods. In the database, they provided germination capacity data for the most successful germination method. Germination data was also published for Salvia (Nyárádi-Szabady et al. 1992) and Erysimum species (Csontos et al. 2010), and for rare and protected herbs such as Vicia biennis (Endrédi 2012, Endrédi et al. 2012), Trifolium vesiculosum (Endrédi 2012) and Astragalus contortuplicatus (Lovas-Kiss et al. 2015, Molnár V. et al. 2015) and the recently discovered alien Cochlearia danica (Fekete et al. 2018). Kövendi-Jakó et al. (2016) published germination records for 12 dry grassland species.

However, data on the germination capacity of the Pannonian flora under near-natural conditions are still scarce. Knowledge of the germination capacity of the regional flora would not only be useful in germination experiments, but would also provide information for restoration projects. By studying germination capacity of seeds, we should answer questions such as how a community would regenerate after a disturbance, or which species could be used for restoration purposes. Our aim was to provide data regarding the germination capacity of herbaceous species of the Hungarian flora under near-natural controlled conditions. Among the analysed species there were target species of ecological restoration projects and also weeds and invasive species that can pose problems for nature conservation. We also tested the year-to-year variability of the germination capacity of 20 species collected from the same populations in three consecutive years.

\section{MATERIALS AND METHODS}

Seeds were collected in the Carpathian Basin between 2006 and 2017 (for locations and dates, see Tables 1 and 2). Most of the seeds originated from the Great Hungarian Plain. One species (Erophila verna) was collected in Romania. Seeds were collected after maturation (Tables 1 and 2) and dry-stored until the germination experiments. In the case of five short-lived Brassicaceae species a long time period elapsed between their collection and germination (Miglécz et al. 2013), but they are known for their long-lived seeds so the longer time period had no effect on their germination capacity. In the case of the other 70 species, seeds were germinated in the year of collection or in the following year (details given in Tables 1 and 2). Before germination, seeds were cleaned, and only intact seeds were used in the experiments. We used $8 \mathrm{~cm} \times 8 \mathrm{~cm} \times 12$ $\mathrm{cm}$ pots, filled with potting soil. We placed 25,50 or 100 seeds on each pot. The pots were ordered randomly and placed under natural light in room temperature, or were placed in unheated greenhouses. The number of seeds per pot, 


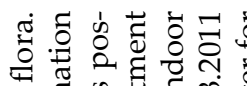

क्ष

व

要

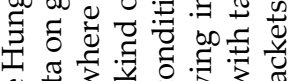

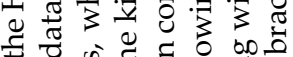

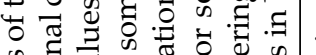

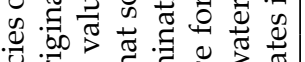

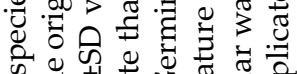

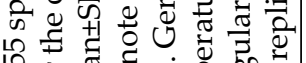

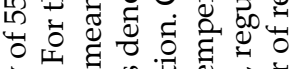

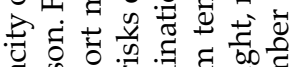

政卷

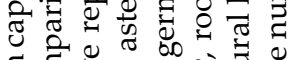

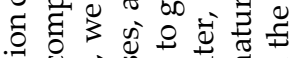

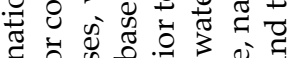

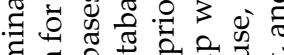

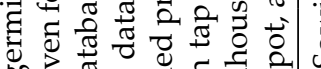

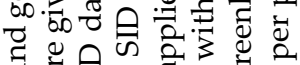

-

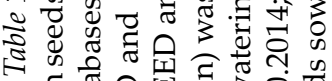

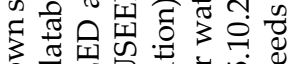

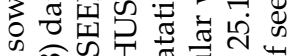

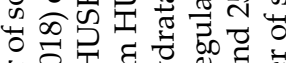

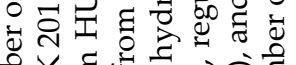

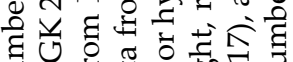

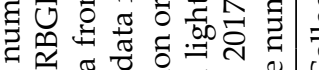

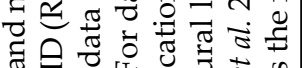

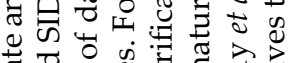

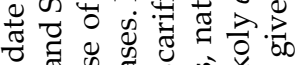

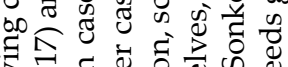

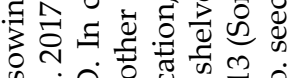

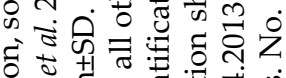

政语:

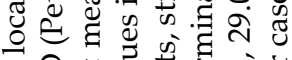

可喏

व

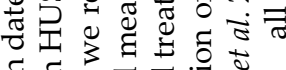

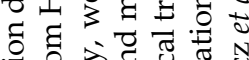

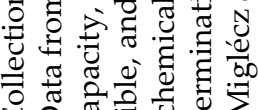

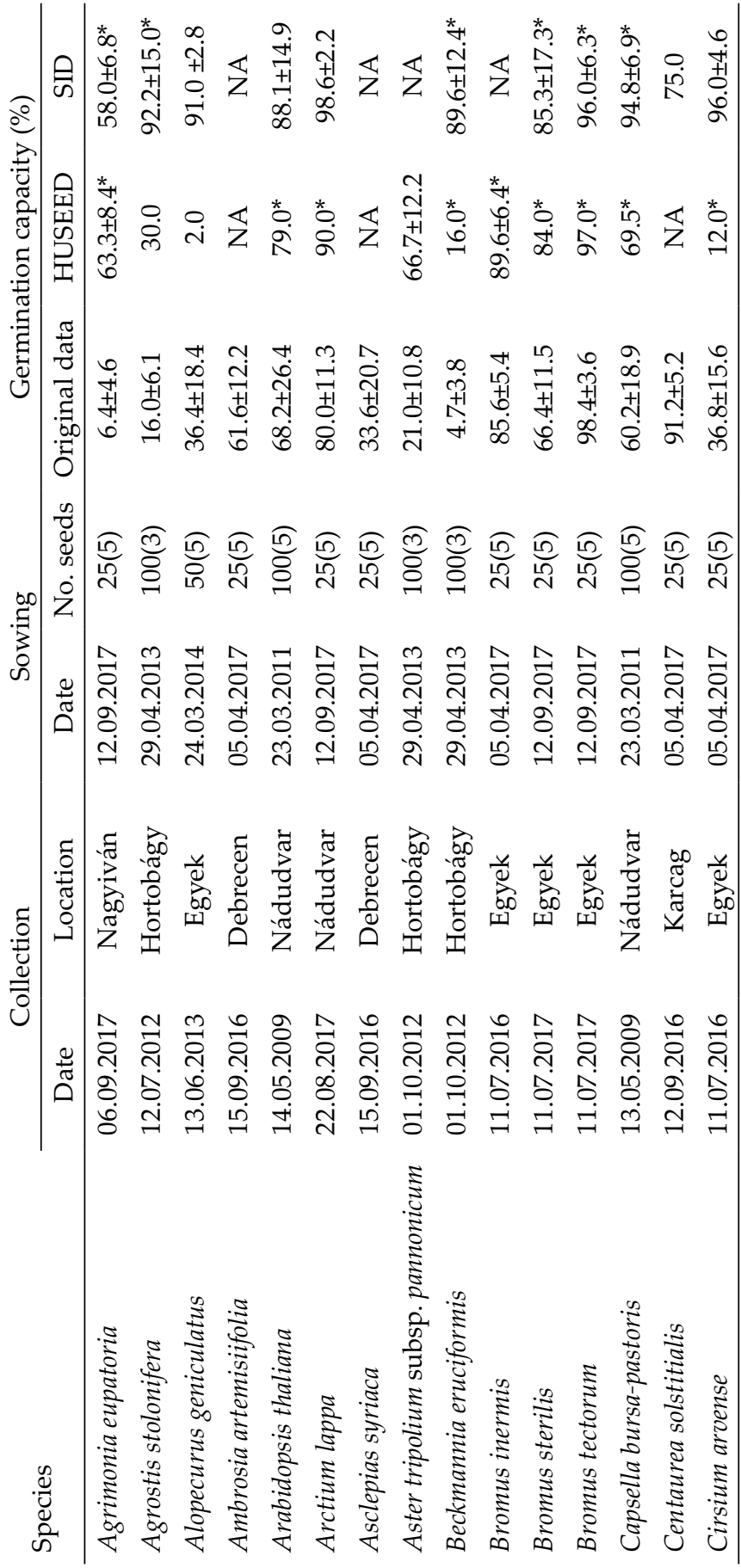




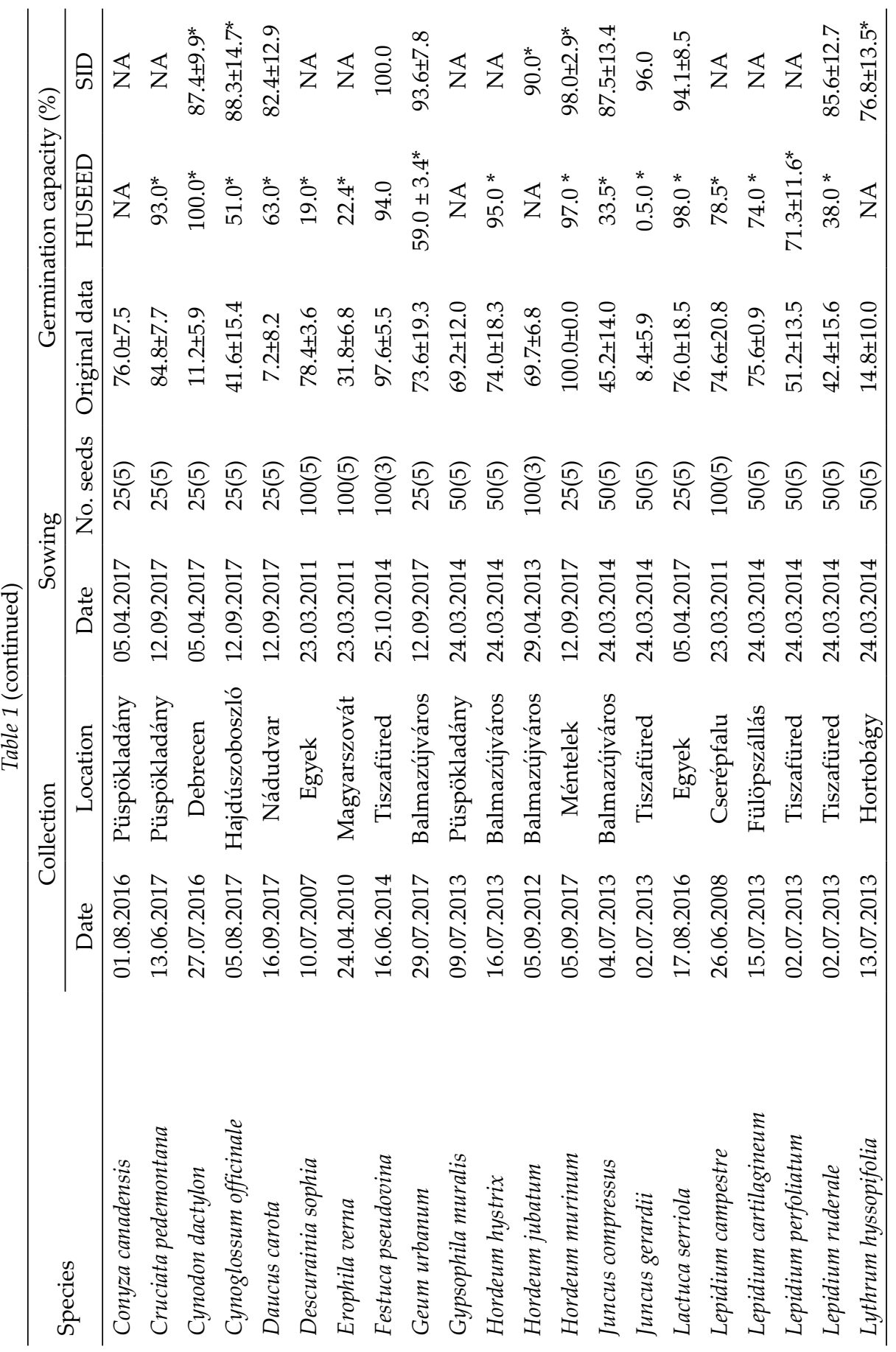




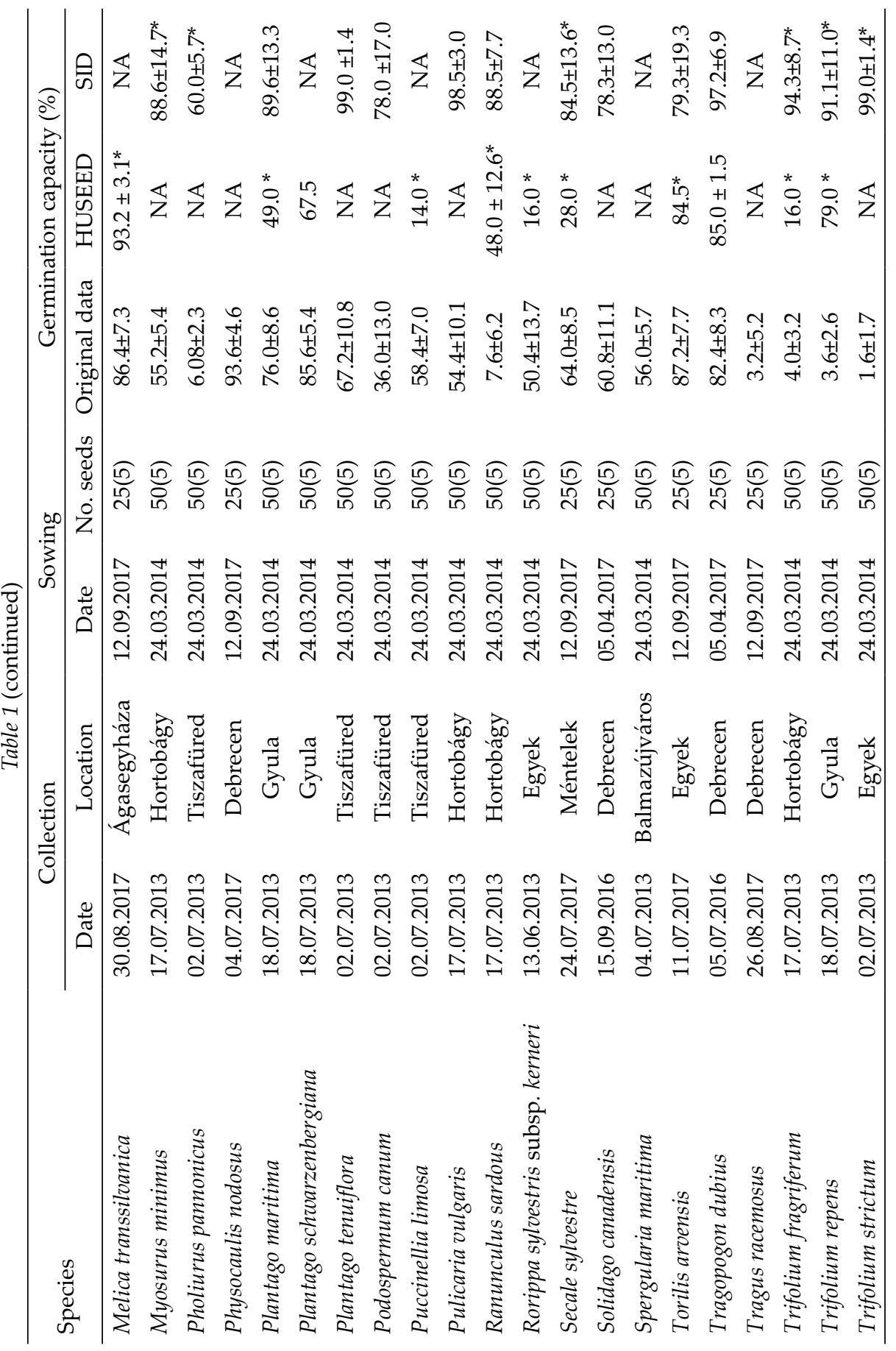




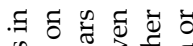

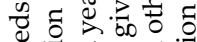

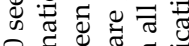

8.9

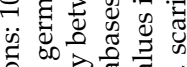

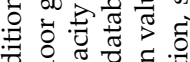

范

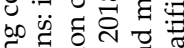

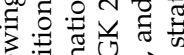

के च छ

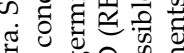

옴

ส

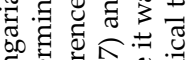

舟

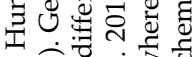

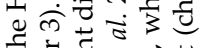

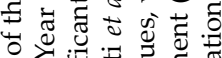

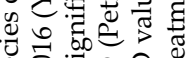

ปั

के

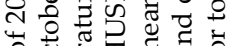

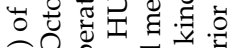

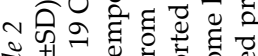

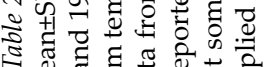

ฮั ส

0ं

D.

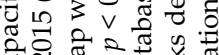

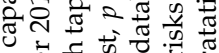

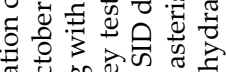

范

घ 월

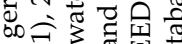

휴

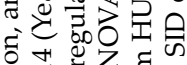

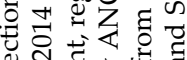

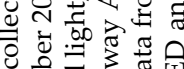

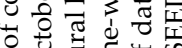

○

ত

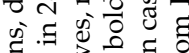

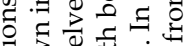

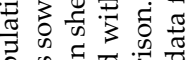

के क्ञ

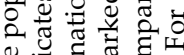

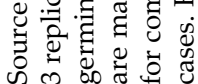

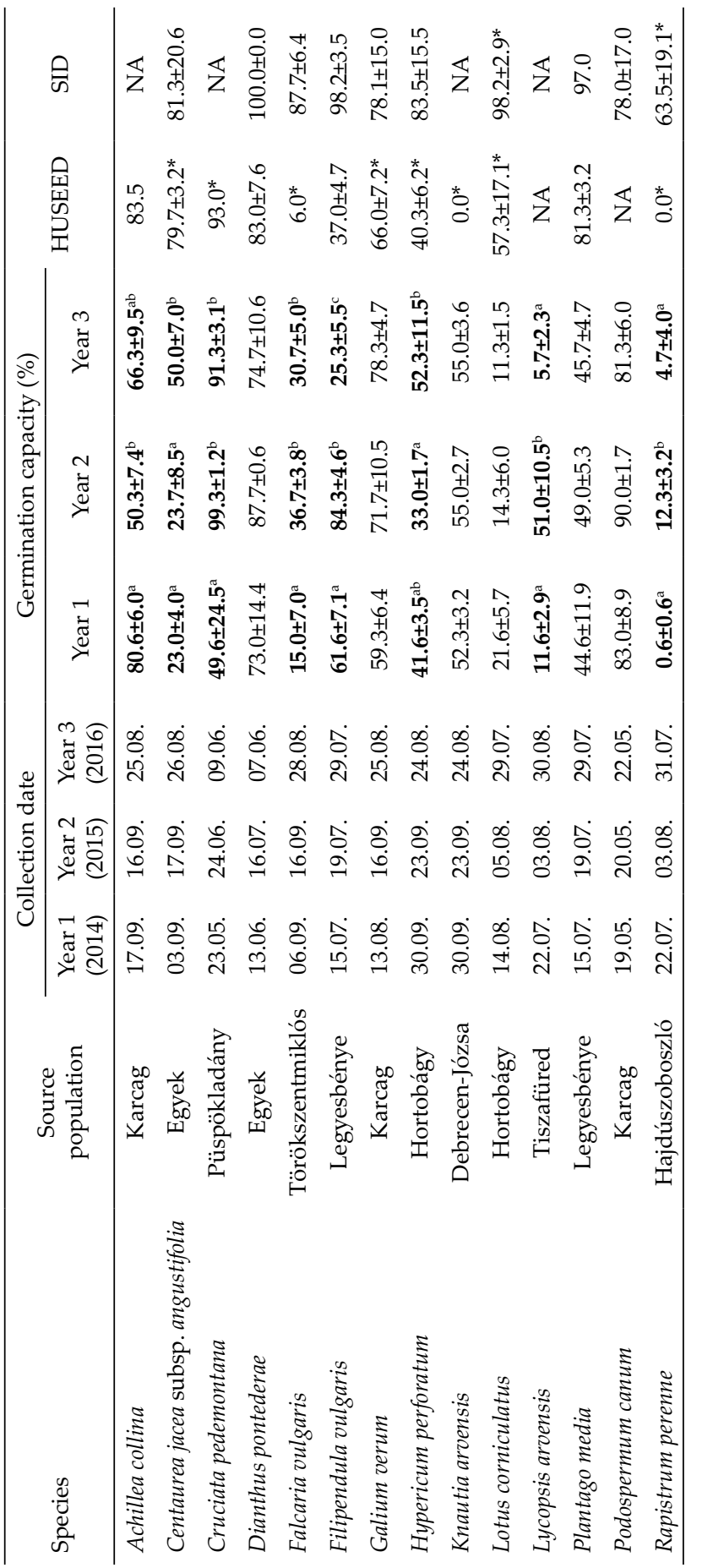




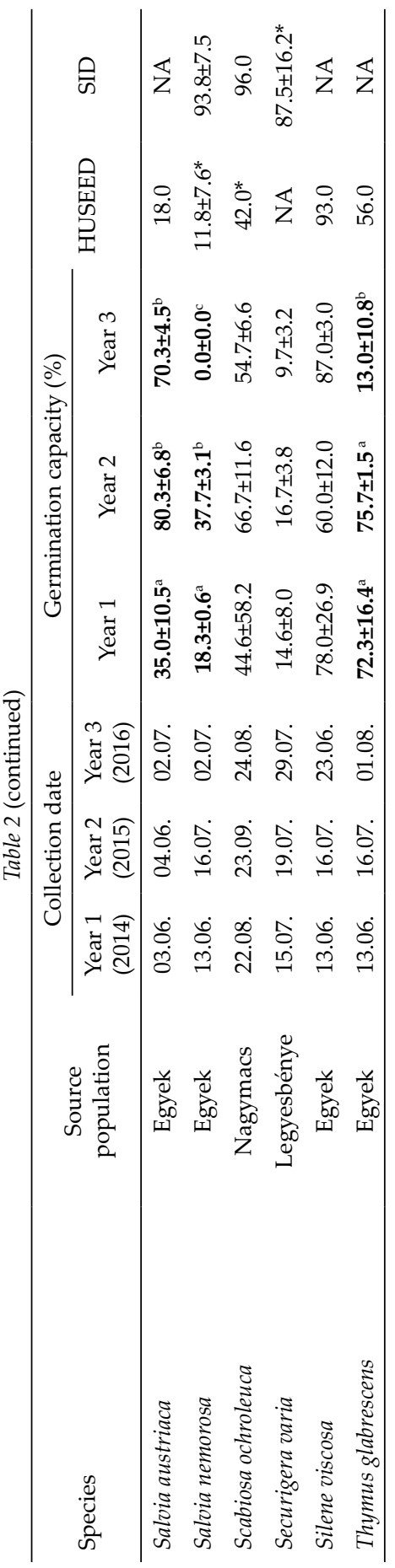

the number of replicates and germination conditions are indicated for each species in Tables 1 and 2. The pots were watered with tap water regularly. Seedlings were counted and removed at weekly intervals. Nomenclature follows Király (2009).

To study the year-to-year variation of the germination capacity of 20 common species of dry grasslands, we collected seeds in the same populations in three consecutive years (Table 2). The yearly variation of the seed germination capacity of 20 species in three consecutive years was tested using one-way ANOVA and Tukey's tests in R.

\section{RESULTS}

We provided data on the germination capacity of 75 species under controlled conditions, at room temperature or in a greenhouse. We reported the germination capacity of 20 species not included in HUSEED and 26 not included in SID, of which 8 species were new to both databases. The mean and standard deviation of the germination capacity found in our study is shown in Table 1 , and, as comparison, mean scores from HUSEED and SID databases are also given. The lowest germination capacities - below $5 \%$ - were observed for legumes, such as Trifolium strictum (1.6\%), Trifolium repens $(3.6 \%)$, Trifolium fragiferum $(4.0 \%)$ and grasses, such as Tragus racemosus (3.2\%) and Beckmannia eruciformis (4.7\%). The highest germination capacities were recorded for grasses (Festuca pseudovina, Bromus tectorum and Hordeum murinum) reaching 97.6\%, $98.4 \%$ and $100 \%$, respectively.

Year-to-year differences in the germination capacity of 20 dry grassland species are shown in Table 2. There were significant 
yearly differences in the germination capacity of 11 species. Rapistrum perenne had the lowest mean germination capacity $(5.9 \%)$, having a maximum germination capacity of $12.3 \%$. Hard-seeded species, such as Securigera varia, Lotus corniculatus and Salvia nemorosa also had a mean germination capacity below 20\%; Salvia nemorosa showed significant differences between years. Cruciata pedemontana and Podospermum canum had the highest germination capacities with a mean of $80.1 \%$ and $84.8 \%$, respectively.

\section{DISCUSSION}

We provided original data on the germination capacity of 75 species of the Hungarian flora. Compared to the other available germination databases (HUSEED, SID), we used potting soil as a germination substrate, we did not regulate the temperature or dark/light periods, and we sowed seeds without any pre-treatment. Thus, our dataset can give important insights into the germination capacity of plant species under near-natural conditions. This knowledge will support restoration projects in the composition of ideal seed mixtures, containing species that can germinate successfully without additional treatments. Records of the germination capacity of weeds and invasive species can also be informative in nature conservation projects. Our study also highlights that germination capacity can be highly variable between years. This implies that, for successful restoration, the germination capacity of the sown species should be tested in multiple years, and in large-scale projects those species should be prioritized that germinate similarly well every year.

Acknowledgements - We are grateful to László Papp and the Botanical Garden of the University of Debrecen, for providing space for the germination experiments. The study was supported by the OTKA PD 111807, NKFI FK 124404, NKFI KH 126476 (OV), OTKA K 116639, NKFI KH 126477 (BT), OTKA PD 115627 (BD), NKFI K 119225 (PT), NKFI PD 124548 (TM), NKFI PD 128302 (KT). OV, KL and BD were supported by the New National Excellence Program of the Hungarian Ministry of Human Capacities. OV and BD were supported by the Bolyai János Research Scholarship of the Hungarian Academy of Sciences.

\section{REFERENCES}

Akinola, M. O., Thompson, K. and Buckland, S. M. (1998): Soil seed bank of an upland calcareous grassland after 6 years of climate and mangement manipulations. - J. Appl. Ecol. 35: 544-552. https://doi.org/10.1046/j.1365-2664.1998.3540544.x

Baskin, C. C. and Baskin, J. M. (eds) (1998): Seeds: ecology, biogeography, and evolution of dormancy and germination. - Academic Press, San Diego, 666 pp. 
Bossuyt, B. and Honnay, O. (2008): Can the seed bank be used for ecological restoration? An overview of seed bank characteristics in European communities. - J. Veg. Sci. 19: 875-884. https://doi.org/10.3170/2008-8-18462

Budelsky, R. A. and Galatowitsch, S. M. (1999): Effects of moisture, temperature and time on seed germination of five wetland Carices: implications for restoration. - Restoration Ecol. 7: 86-97. https://doi.org/10.1046/j.1526-100x.1999.07110.x

Covell, S., Ellis, R. H., Roberts, E. H. and Summerfield, R. J. (1986): The influence of temperature on seed germination rate in grain legumes: I. A comparison of chickpea, lentil, soybean and cowpea at constant temperatures. - J. Exp. Bot. 37: 705-715. https:// doi.org/10.1093/jxb/37.5.705

Csontos, P., Rucinska, A. and Puchalski, J. T. (2010): Germination of Erysimum pieninicum and Erysimum odoratum seeds after various storage conditions. - Tájökol. Lapok 8: 389-394.

Deák, B., Valkó, O., Kelemen, A., Török, P., Miglécz, T., Ölvedi, T., Lengyel, S. and Tóthmérész, B. (2011): Litter and graminoid biomass accumulation suppresses weedy forbs in grassland restoration. - Plant Biosystems 145: 730-737. https://doi.org/10.1080/112 63504.2011.601336

Endrédi, A. (2012): Védett növények ex-situ védelme. - Magiszteri dolgozat, Budapest.

Endrédi, A., Molnár, A. and Nagy, J. (2012): A kunsági bükköny (Vicia biennis L.) ex-situ védelme. - Term.véd. Közlem. 18: 150-158.

Fekete, R., Mesterházy, A., Valkó, O. and Molnár V., A. (2018): A hitchhiker from the beach - the spread of a maritime halophyte (Cochlearia danica L.) along salted continental roads. - Preslia 90(1): 23-37. https://doi.org/10.23855/preslia.2018.023

Gulzar, S. and Khan, M. A. (2001): Seed germination of a halophytic grass Aeluropus lagopoides. - Ann. Bot. 87: 319-324. https://doi.org/10.1006/anbo.2000.1336

Hintze, C., Heydel, F., Hoppe, C., Cunze, S., König, A. and Tackenberg, O. (2013): D²: the dispersal and diaspore database - baseline data and statistics on seed dispersal. Pers. Plant Ecol., Evol. Syst. 15: 180-192. https://doi.org/10.1016/j.ppees.2013.02.001

Huang, Z., Zhang, X., Zheng, G. and Gutterman, Y. (2003): Influence of light, temperature, salinity and storage on seed germination of Haloxylon ammodendron. - J. Arid Environm. 55: 453-464. https://doi.org/10.1016/s0140-1963(02)00294-x

ISTA (2018): International seed testing association. - https://www.seedtest.org/en/home.html)

Kelemen, A., Török, P., Valkó, O., Deák, B., Tóth, K. and Tóthmérész, B. (2015): Both facilitation and limiting similarity shape the species coexistence in dry alkali grasslands. - Ecol. Complexity 21: 34-38. https://doi.org/10.1016/j.ecocom.2014.11.004

Kelemen, A., Valkó, O., Kröel-Dulay, Gy., Deák, B., Török, P., Tóth, K., Miglécz, T. and Tóthmérész, B. (2016): The invasion of common milkweed (Asclepias syriaca L.) in sandy old-fields - is it a threat to the native flora? - Appl. Veg. Sci. 19: 218-224. https:// doi.org/10.1111/avsc.12225

Kimura, H. and Tsuyuzaki, S. (2011): Fire severity affects vegetation and seed bank in a wetland. - Appl. Veg. Sci. 14: 350-357. https://doi.org/10.1111/j.1654-109x.2011.01126.x

Király, G. (ed.) (2009): Új Magyar Füvészkönyv. Magyarország hajtásos növényei. Határozókulcsok. - Aggtelek National Park Directorate, Jósvafő, 504 pp.

Kleyer, M., Bekker, R., Bakker, J., Knevel, I., Thompson, K., Sonnenschein, M., Poschlod, P., van Groenendael, J., Klimeš, L., Klimešova, J., Klotz, S., Rusch, G., Hermy, M., Adriaens, D., Boedeltje, G., Bossuyt, B., Endels, P., Götzenberger, L., Hodgson, J., Jackel, A., Dannemann, A., Kühn, I., Kunzmann, D., Ozinga, W., Römermann, C., 
Stadler, M., Schlegelmilch, J., Steendam, H., Tackenberg, O., Wilmann, B., Cornelissen, J., Eriksson, O., Garnier, E., Fitter, A. and Peco, B. (2008): The LEDA traitbase: a database of plant life-history traits of North West Europe. - J. Ecol. 96: 1266-1274. https://doi.org/10.1111/j.1365-2745.2008.01430.x

Kövendi-Jakó, A., Csecserits, A., Halassy, M., Halász, K., Szitár, K. and Török, K. (2016): Relationship of germination and establishment for twelve plant species in restored dry grassland. - Appl. Ecol. Environm. Res. 15: 227-239. https:// doi.org/10.15666/aeer/1504_227239

Kozlowski, T. T. (ed.) (2012): Germination control, metabolism, and pathology. Vol. 2. - Academic Press Inc., U.S., 447 pp.

Lovas-Kiss, Á., Sonkoly, J., Vincze, O., Green, A. J., Takács, A. and Molnár V., A. (2015): Strong potential for endozoochory by waterfowl in a rare, ephemeral wetland plant species, Astragalus contortuplicatus (Fabaceae). - Acta Soc. Bot. Poloniae 84: 321-326. https://doi.org/10.5586/asbp.2015.030

Miglécz, T., Tóthmérész, B., Valkó, O., Kelemen, A. and Török, P. (2013): Effects of litter on seedling establishment: an indoor experiment with short-lived Brassicaceae species. - Plant Ecol. 214: 189-193. https://doi.org/10.1007/s11258-012-0158-6

Molnár V., A., Sonkoly, J., Lovas-Kiss, Á., Fekete, R., Takács, A., Somlyay, L. and Török, P. (2015): Seed of the threatened annual legume, Astragalus contortuplicatus, can survive over 130 years of dry storage. - Preslia 87 : 319-328.

Nyárádi-Szabady, J., Dános, B. and Bernáth, J. (1992): Data concerning the germination biology of Salvia species native in Hungary. - Acta Horticulturae 306: 313-318. https:// doi.org/10.17660/actahortic.1992.306.39

Patanè, C. and Gresta, F. (2006): Germination of Astragalus hamosus and Medicago orbicularis as affected by seed-coat dormancy breaking techniques. - J. Arid Environm. 67: 165-173. https://doi.org/10.1016/j.jaridenv.2006.02.001

Peti, E., Schellenberger, J., Németh, G., Málnási Csizmadia, G., Oláh, I., Török, K., Czóbel, S. and Baktay, B. (2017): Presentation of the HUSEEDwild, a seed weight and germination database of the Pannonian flora, through analysing life forms and social behaviour types. - Appl. Ecol. Environm. Res. 15: 225-244. https:// doi.org/10.15666/aeer/1501_225244

Roberts, E. H. H. (1988): Temperature and seed germination. - Symp. Soc. Exp. Biol. 42: 109-132.

Royal Botanic Gardens Kew (2018): Seed Information Database (SID). Version 7.1. Available from: http://data.kew.org/sid/ (January 2018)

Sonkoly, J., Valkó, O., Deák, B., Miglécz, T., Tóth, K., Radócz, S., Kelemen, A., Riba, M., Vasas, G., Tóthmérész, B. and Török, P. (2017): A new aspect of grassland vegetation dynamics: cyanobacterium colonies affect establishment success of plants. - J. Veg. Sci. 28: 475-483. https://doi.org/10.1111/jvs.12503

Török, P., Deák, B., Vida, E., Valkó, O., Lengyel, S. and Tóthmérész, B. (2010): Restoring grassland biodiversity: sowing low-diversity seed mixtures can lead to rapid favourable changes. - Biol. Conservation 143: 806-812. https://doi.org/10.1016/j.biocon.2009.12.024

Török, P., Vida, E., Deák, B., Lengyel, S. and Tóthmérész, B. (2011): Grassland restoration on former croplands in Europe: an assessment of applicability of techniques and costs. Biodiv. and Conservation 20: 2311-2332. https://doi.org/10.1007/s10531-011-9992-4

Török, P., Miglécz, T., Valkó, O., Tóth, K., Kelemen, A., Albert, Á., Matus, G., Molnár V., A., Ruprecht, E., Papp, L., Deák, B., Horváth, O., Takács, A., Hüse, B. and Tóthmérész, 
B. (2013): New thousand-seed weight records of the Pannonian flora and their application in analysing social behaviour types. - Acta Bot. Hung. 55: 429-472. https:// doi.org/10.1556/abot.55.2013.3-4.17

Török, P., Tóth, E., Tóth, K., Valkó, O., Deák, B., Kelbert, B., Bálint, P., Radócz, Sz., Kelemen, A., Sonkoly, J., Miglécz, T., Matus, G., Takács, A., Molnár V., A., Süveges, K., Papp, L., Papp, L. jr., Tóth, Z., Baktay, B., Málnási Csizmadia, G., Oláh, I., Peti, E., Schellenberger, J., Szalkovszki, O., Kiss, R. and Tóthmérész, B. (2016): New measurements of thousand-seed weights of species in the Pannonian Flora. - Acta Bot. Hung. 58: 187-198. https://doi.org/10.1556/034.58.2016.1-2.10

Valkó, O., Tóthmérész, B., Kelemen, A., Simon, E., Miglécz, T., Lukács, B. and Török, P. (2014): Environmental factors driving vegetation and seed bank diversity in alkali grasslands. - Agriculture, Ecosystems and Environment 182: 80-87. https:// doi.org/10.1016/j.agee.2013.06.012

Valkó, O., Deák, B., Török, P., Kirmer, A., Tishew, S., Kelemen, A., Tóth, K., Miglécz, T., Radócz, S., Sonkoly, J., Tóth, E., Kiss, R., Kapocsi, I. and Tóthmérész, B. (2016): Highdiversity sowing in establishment gaps: a promising new tool for enhancing grassland biodiversity. - Tuexenia 36: 359-378. https://doi.org/10.14471/2016.36.020

Valkó, O., Tóth, K., Kelemen, A., Miglécz, T., Sonkoly, J., Tóthmérész, B., Török, P. and Deák, B. (2018): Cultural heritage and biodiversity conservation - plant introduction and practical restoration on ancient burial mounds. - Nature Conservation 24: 65-80. https://doi.org/10.3897/natureconservation.24.20019 